\title{
PENERAPAN MODEL PEMBELAJARAN INKUIRI TERBIMBING TERHADAP KEMAMPUAN KOGNITIF SISWA PADA MATERI PERUBAHAN LINGKUNGAN DAN DAUR ULANG LIMBAH KELAS X DI SMA
}

\author{
Awalul Fatiqin ${ }^{3 *}$, Amilda ${ }^{2}$, Helen Monica Sari ${ }^{3}$ \\ Universitas Islam Negeri Raden Fatah Palembang Jl. Prof. K.H. Zainal Abidin Fikri No. 1 A \\ KM 3,5, Palembang 30126, Indonesia \\ *Email : awalulfatiqin_uin@radenfatah.ac.id
}

\begin{abstract}
This study aims to determine the Differences of Cognitive Ability of Students Before and After Application of Guided Inquiry Learning Model on Environmental Change Material and Waste Recycling Class X in SMA 'Aisyiyah 1 Palembang. The research method used in this research is weak experiment with one group pretest-posttest design. The population in this study consists of one class of 38 students. Sampling in this research using saturated sample technique because the entire population is sampled. Technique of collecting data is done with test question and observation sheet. Based on the results of data using $\mathrm{t}$ test at the real level of $5 \% \mathrm{t}_{\text {count }}=7,607$ and $\mathrm{t}_{\text {table }}=2.026$, then $\mathrm{t}_{\text {count }}>\mathrm{t}_{\text {table }}$. This can be seen from the cognitive test of students showed sig $t_{\text {hitung }} 0.000<0,05$, then $\mathrm{Ha}$ accepted and $\mathrm{H} 0$ rejected. The result of the analysis of the average increase of the students 'cognitive achievement on the pretest reaches 69.34 while the cognitive students in the posttest reach 83.82 means students' cognitive ability is higher after the application of guided inquiry learning model. Then it can be deduced that there is a Difference of Cognitive Ability of Students Before and After Application of Guided Inquiry Learning Model.
\end{abstract}

Keywords: Guided Inquiry Learning Model; Student Cognitive.

\section{PENDAHULUAN}

Ilmu pengetahuan dan teknologi yang berkembang sangat pesat berdampak pada perubahan berbagai aspek kehidupan manusia, salah satunya adalah permasalahan di bidang pendidikan. Pendidikan yang mampu mengatasi permasalahan dan mendukung pembangunan di masa mendatang adalah pendidikan yang mampu mengembangkan potensi peserta didik sehingga mereka mampu menghadapi dan memecahkan permasalahan kehidupan yang dihadapinya (Trianto, 2011: 1). Salah satu upaya yang perlu dilakukan agar potensi peserta didik dapat dikembangkang secara maksimal ialah dengan melaksanakan pendidikan abad 21.
Arah pendidikan abad 21 ini sangat relevan dengan tujuan pendidikan di Indonesia sebagaimana tercantum pada Undang Undang Nomor 20 Tahun 2003, yaitu Pendidikan Nasional berfungsi untuk mengembangkan kemampuan dan membentuk watak serta peradaban bangsa, yang bermartabat dalam rangka mencerdaskan kehidupan bangsa, untuk mengembangkan potensi peserta didik agar menjadi manusia yang beriman dan bertakwa kepada Tuhan Yang Maha Esa, berakhlak mulia, sehat, berilmu, cakap, kreatif, mandiri, dan menjadi warga negara yang demokratis serta bertanggungjawab (Sudarisman, 2015: 250). Upaya yang dapat dilakuakan untuk mencapai tujuan 
pendidikan abad 21 adalah meningkatkan ranah kognitif peserta didik.

Setiap peserta didik memiliki kemampuan kognitif yang berbeda-beda tergantung bagaimana dan sejauh apa kemampuan tersebut dilatihkan. Menurut Anderson dan Kratwohl (2001: 66), kemampuan kognitif terbagi menjadi enam tingkatan, yaitu mengingat $(\mathrm{C} 1)$, memahami (C2), menerapkan (C3), menganalisis (C4), mengevaluasi (C5) dan menciptakan (C6). Sehingga dengan model pembelajaran inkuiri terbimbing dapat membeikan pemahaman siswa pada materi perubahan lingkungan secara merata pada setiap siswa untuk membentuk satuan pembelajaran yang komprehensif.

Proses pembelajaran Biologi adalah suatu sistem, pada prisipnya merupakan kesatuan yang tidak terpisahkan antara komponen raw input (peserta didik), instrumental input (masukan instrumental), lingkungan, dan output (hasil keluaran). Keempat komponen tersebut mewujudkan sebuah sistem pembelajaran Biologi dengan pusat utamanya yaitu proses. Pembelajaran Biologi mencakup semua materi terkait dengan objek alam dan persoalannya. Ruang lingkup Biologi mengkaji pada persoalan yang berhubungan dengan makhluk hidup serta lingkungannya. Penerapan pendidikan Biologi di sekolah menengah bertujuan agar siswa memahami dan menguasai konsep alam serta dapat menggunakan metode ilmiah untuk menyelesaikan persoalan alam tersebut (Suhardi, 2007: 4).

Berdasarkan observasi yang telah dilakukan oleh penulis/peneliti di kelas $\mathrm{X}$ SMA 'Aisyiyah 1 Palembang diperoleh fakta bahwa; siswa kelas X masih banyak siswa yang mendapatkan nilai Biologi di bawah Kriteria Ketuntasan Minimal dan masih banyak siswa yang masih mengalami kesulitan dalam menerima serta memahami materi Biologi. Kriteria Ketuntasan Minimal (KKM) di SMA 'Aisyiyah 1 Palembang yaitu 75 , akan tapi hanya $40 \%$ nilai siswa yang mencapai KKM dan $60 \%$ nilai siswa belum mencapai KKM. Selain itu, metode yang sering digunakan dalam proses pembelajaran biologi adalah ceramah dan hapalan sehingga menyebabkan peserta didik merasa jenuh dan bosan. Selama ini, proses pembelajaran lebih cenderung kearah teacher centered sehingga peserta didik kurang aktif dalam pembelajaran. Pembelajaran seperti ini menunjukkan bahwa pembelajaran masih berpusat pada guru, sehingga peserta didik hanya mendengar dan memperhatikan tanpa berpartisipasi secara aktif. Hal tersebut tentu akan berpengaruh pada pencapaian hasil belajar peserta didik.

Berdasarkan uraian di atas, maka diperlukan adanya model pembelajaran yang mampu meningkatkan kemampuan kognitif peserta didik. Salah satu model pembelajaran yang memberikan kesempatan bagi siswa peserta didik untuk menemukan sendiri pengetahuannya, berfikir aktif dalam pembelajaran dan mengembangkan kemampuan berpikir peserta didik adalah model pembelajaran inkuiri terbimbing.

Model pembelajaran inkuiri terbimbing adalah salah satu cara dalam pembelajaran berbasis inkuiri yang digunakan dalam pendidikan sains. Pembelajaran inkuiri terbimbing diawali dari permasalahan yang diajukan guru, kemudian siswa melakukan pengamatan sampai pada kegiatan menyimpulkan (Trianto, 2011: 2).

Menurut Susanti (2014: 17), dalam penelitiannya tentang pengaruh model pembelajaran inkuiri terbimbing terhadap hasil belajar sains biologi siswa kelas VII 
SMP N 1 Ngawen, mahasiswa UIN Sunan Kalijaga Yogyakarta menunjukkan bahwa pembelajaran inkuiri terbimbing terbukti berpengaruh terhadap hasil belajar kognitif peserta didik. Peserta didik memberikan tanggapan yang baik terhadap penggunaan model inkuiri terbimbing dengan persentase sebesar $66,67 \%$.

Sehubungan dengan kekurangan model pembelajaran inkuiri terbimbing yaitu tidak semua topik materi pelajaran cocok untuk disampaikan dengan model ini (Sanjaya, 2011: 208). Maka dari itu, pada penelitian ini mengambil topik materi pelajaran yaitu perubahan lingkungan dan daur ulang limbah.

Menurut Roestiyah (2001: 76), kelebihan model pembelajaran inkuiri terbimbing dapat membentuk dan mengembangkan "self-concept" pada peserta didik, sehingga siswa dapat mengerti tentang konsep dasar dan peserta didik memiliki ide-ide yeng lebih baik, membantu dalam menggunakan ingatan dan transfer informasi pada situasi dan proses belajar yang baru, mendorong peserta didik untuk berfikir dan bekerja atas inisiatifnya sendiri, bersikap objektif, jujur dan terbuka, situasi proses belajar mengajar menjadi lebih baik, dapat mengembangkan bakat atau kecakapan individu serta dapat memberikan kebebasan peserta didik untuk belajar sendiri.

Sehubungan dengan uraian tersebut maka penelitian yang perlu dikukan yaitu "Penerapan Model Pembelajaran Inkuiri Terbimbing Terhadap Kemampuan Kognitif Siswa Pada Materi Perubahan Lingkungan Dan Daur Ulang Limbah Kelas X Di SMA”.

\section{METODE PENELITIAN}

Penelitian ini dilakukan pada 9 Mei 2017 sampai 19 Mei 2017, bertempat di SMA 'Aisyiyah 1 Palembang. Penelitian ini menggunakan jenis penelitian weak eksperiment design dengan desain one group pretest-posttest design. Pengambilan sampel pada penelitian ini menggunakan teknik sampling jenuh, dikarenakan semua sampel pada penelitian ini merupakan populasi. Pada penelitian ini yang menjadi variabel bebas (X) yaitu model pembelajaran inkuiri terbimbing, dan variabel terikatnya adalah kemampuan kognitif peserta didik.

Teknik yang digunakan untuk pengambilan dan pengumpulan data dalam penelitian ini berupa tes soal dan lembar observasi. Tes merupakan data primer (data utama) dalam penelitian sedangkan lembar observasi sebagai data sekunder (data pendukung) penelitian.

\section{HASIL DAN PEMBAHASAN}

Kemampuan kognitif peserta didik yang dikaji pada penelitian ini meliputi beberapa indikator : mengingat (C1), memahami (C2), mengaplikasikan (C3), menganalisis (C4), mengevaluasi (C5) dan menciptakan (C6) (Anderson dan Kratwohl, 2001: 66). Penelitian ini menggunakan satu kelas yakni sebelum dilakukan pembelajaran siswa diberi tes awal (pretest) selanjutnya setelah penerapan model pembelajaran inkuiri terbimbing siswa diberikan tes akhir (posttest).

Hasil penelitian didukung juga dari lembar observasi yang bertujuan untuk melihat keterlaksanaan model pembelajaran inkuiri terbimbing apakah terlaksana dengan baik atau tidak. Menurut Trianto (2012: 172), tahapan model pembelajaran inkuiri terbimbing meliputi: 1) menyajikan masalah, 2) membuat hipotesis, 3) merancang percobaan, 4) melakukan percobaan untuk memperoleh informasi, 5) mengumpulkan 
dan menganalisis data, 6) membuat kesimpulan.

\section{Hasil Penelitian}

\section{Hasil Perbedaan Data Pretest dan Posttest}

Setelah dilakukan penskoran terhadap hasil pretest dan posttest dari kelas X IPA,

Tabel 1. Hasil Pretest dan Posttest

\begin{tabular}{ccc}
\hline Data & Pretest & Posttest \\
\hline Nilai Terendah & 50 & 60 \\
Nilai Tertinggi & 85 & 100 \\
Rata-Rata & 69,34 & 83,82 \\
Jumlah Siswa & 38 & 38 \\
\hline
\end{tabular}

Berdasarkan Tabel di atas dapat dilihat nilai bahwa rata-rata nilai pretest sebesar 69,34 termasuk ke dalam kriteria tidak tuntas dan rata-rata nilai posttest sebesar 83,82 termasuk ke dalam kriteria tuntas.

Berdasarkan Tabel dan penjelasan tersebut, dapat disimpulkan bahwa terdapat diperoleh data. Data penelitian dianalisis dengan menggunakan software SPSS versi 16.0. Hasil perhitungan data tersebut dapat dilihat pada Tabel 1.

Tabel 2. Persentase Ketuntasan Kemampuan Kognitif Siswa

\begin{tabular}{clcc}
\hline No & \multicolumn{1}{c}{ Indikator } & \multicolumn{2}{c}{ Persentase Ketuntasan } \\
& & \multicolumn{1}{c}{ Pretest } & Posttest \\
\cline { 3 - 4 } & & $89,47 \%$ & $92,18 \%$ \\
\hline 1. & (C1) Mengingat & $86,84 \%$ & $87,01 \%$ \\
2. & (C2) Memahami & $62,49 \%$ & $84,27 \%$ \\
3. & (C3) Mengaplikasikan & $61,18 \%$ & $82,95 \%$ \\
4. & (C4) Menganalisis & $68,41 \%$ & $80,69 \%$ \\
5. & (C5) Mengevaluasi & $60,52 \%$ & $75,43 \%$ \\
6. & (C6) Mencipta & & \\
\hline
\end{tabular}

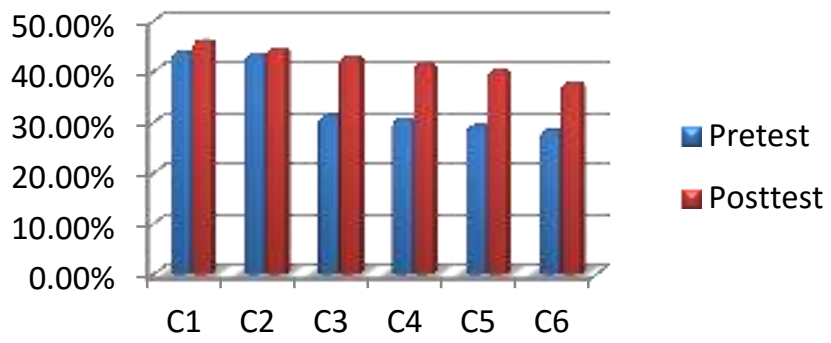

Gambar 1. Diagram Batang Persentase Ketuntasan Kemampuan Kognitif Siswa

Berdasarkan Gambar 1 menunjukkan perbedaan setiap indicator sebelum dan setelah proses pembelajaran inkuiri terbimbing, pada indicator C1 perbedaan kemampuan siswa sebelum dan setelah penerapan model pembelajaran inkuiri terbimbing.

Data persentase ketuntasan dari perbedaan kemampuan kognitif siswa perindikator dapat dilihat pada Tabel 2: terdapatterpaut $2,71 \%$, indicator $\mathrm{C} 2$ terpaut $0.17 \%$, indicator C3 terpaut $21,78 \%$, indicator $\mathrm{C} 4$ terpaut $21,77 \%$, indicator C5 
terpaut $11,98 \%$ dan indicator C6 terpaut $14,91 \%$.

\section{Uji Prasyarat Analisis Pretest dan Posttest}

Setelah diperoleh data, maka dapat dilanjutkan pengujian hipotesisnya, akan tetapi sebelum dilakukan pengujian hipotesis perlu dilakukan uji prasyarat terlebih dahulu terhadap data hasil penelitian yaitu uji normalitas dan uji homogenitas.

\section{Uji Normalitas Data}

Pengujian normalitas, dimaksudkan untuk mengetahui apakah data yang diperoleh berdistribusi normal atau tidak. Uji normalitas digunakan dengan bantuan program SPSS 16.0 terknik KolmogorovSmirnow. Berikut adalah hasil uji normalitas data yang di dapat dari output SPSS. Berdasarkan hasil uji normalitas seperti yang terlihat pada Tabel 3 menunjukkan bahwa nilai signifikasi data hasil pretest $0,120>$ 0,05 maka dapat dikatakan data hasil pretest terdistribusi normal dan nilai signifikasi data hasil postest $0,223>0,05$ sehingga dapat dinyatakan data hasil postest juga terdistribusi normal.

\begin{tabular}{cccc}
\multicolumn{4}{c}{ Tabel 3. Hasil Uji Normalitas Pretest dan Posttest } \\
\hline No. & Nilai & Signifikan & Keterangan \\
\hline 1. & Pretest & $0,120>0,05$ & Data normal \\
2. & Posttest & $0,223>0,05$ & Data normal \\
\hline
\end{tabular}

\section{Uji Homogenitas}

Setelah kedua sampel penelitian tersebut dinyatakan berdistribusi normal, selanjutnya dilakukan uji homogenitas. Uji ini dilakukan untuk mengetahui kesamaan varians setiap kelompok data. Uji homogenitas digunakan dengan bantuan program SPSS 16.0 terknik Levene Statistic. Berikut adalah hasil uji normalitas data yang di dapat dari outpot SPSS. Tabel 4 menunjukkan bahwa nilai signifikasi data pretest dan postest $0,431>0,05$ sehingga dapat dinyatakan data pretest dan postest homogen.

Tabel 4. Hasil Uji Homogenitas Pretest dan Posttest

\begin{tabular}{ccl}
\hline Nilai & Signifikan & Keterangan \\
\hline $\begin{array}{c}\text { Pretest dan } \\
\text { Posttest }\end{array}$ & $0,431>0,05$ & Homogen \\
\hline
\end{tabular}

\section{Uji Hipotesis}

Setelah data dinyatakan normal dan homogen, maka uji hipotesis menggunakan uji paired sample t-test dengan bantuan program SPSS versi 16.0. Uji paired sample t-test. Berikut ini merupakan hasil analisis uji t kemampuan kognitif siswa:

Tabel 5. Hasil Uji Hipotesis (Uji-t)

\begin{tabular}{rc}
\hline Nilai $\mathbf{T}_{\text {hitung }}>\mathbf{T}_{\text {tabel }}$ & Keterangan \\
$7,607>2,026$ & $\mathrm{H}_{\mathrm{a}}$ diterima \\
\hline
\end{tabular}

Berdasarkan Tabel 5 di atas, dapat dibaca bahwa nilai signifikansi sebesar 0,000. Nilai tersebut kurang dari 0,05 $(0,000$ $<0,05)$. Sementara itu dalam penelitian ini menggunakan sampel sebanyak 38 orang, maka nilai derajat kebebasan $(\mathrm{dk})=\mathrm{n}-1=$ $38-1=37$ dan taraf kesalahan 5\% untuk uji dua pihak maka dapat diketahui nilai $\mathrm{t}_{\text {tabel }}=$ 
2,026 dan $t_{\text {hitung }}=7,607$. Dari perhitungan tersebut diperoleh 7,607 > 2,026 ( $\mathrm{t}_{\text {hitung }}>$ $\left.\mathrm{t}_{\text {tabel }}\right)$ dan nilai signifikasi yang diperoleh $0,000<0,05$ maka dapat disimpulkan bahwa $\mathrm{H}_{0}$ ditolak dan $\mathrm{H}_{\mathrm{a}}$ diterima, pada pretest dan posttest materi perubahan lingkungan dan daur ulang limbah memiliki kemampuan kognitif yang tidak sama atau berbeda nyata setelah diberi perlakuan dengan menerapkan model pembelajaran inkuiri terbimbing.

\section{Hasil Observasi}

Observasi yang dilakukan dalam penelitian ini bertujuan untuk mengetahui tingkat ketercapaian proses pembelajaran. Berdasarkan observasi yang dilakukan diperoleh data seperti pada Tabel 6 di bawah ini.

Tabel 6. Data Hasil Observasi

\begin{tabular}{llcc}
\hline No. & \multicolumn{1}{c}{$\begin{array}{c}\text { Tahap pembelajaran inkuiri } \\
\text { terbimbing }\end{array}$} & \multicolumn{2}{c}{$\begin{array}{c}\text { Persentase tiap } \\
\text { pertemuan }\end{array}$} \\
\cline { 3 - 4 } & & P1 & P2 \\
\hline 1 & Menyajikan masalah & $\sqrt{ }$ & $\sqrt{ }$ \\
2 & Membuat hipotesis & X & $\sqrt{ }$ \\
3 & Merancang percobaan & $\sqrt{ }$ & $\sqrt{ }$ \\
4 & Melakukan percobaan untuk & $\sqrt{ }$ & $\sqrt{ }$ \\
& memperoleh informasi & & $\sqrt{ }$ \\
5 & Mengumpulkan dan mengelolah data & $\sqrt{ }$ & $\sqrt{ }$ \\
6 & Membuat kesimpulan & $\sqrt{ }$ & $\sqrt{ }$ \\
\hline
\end{tabular}

\section{Pembahasan}

Berdasarkan hasil penelitian, menunjukkan bahwa model pembelajaran inkuiri terbimbing dapat meningkatkan kemampuan kognitif siswa. Hal ini terlihat dari perhitungan, diperoleh nilai rata-rata pretest yaitu 69,34, nilai rata-rata posttest yang didapat yaitu 83,82 dan nilai rata-rata n-gain dari 38 siswa yang dijadikan sampel diperoleh nilai sebesar 0,57 , dengan nilai perhitungan n-gain $>0,7$ diperoleh 17 siswa, 0,3-0.7 diperoleh 14 siswa dan $<0,3$ diperoleh 8 siswa. Perbedaan ini terlihat pada perolehan nilai pretest, nilai di atas 75 terdapat 12 siswa atau $31,58 \%$ dengan kualifikasi tuntas sedangkan yang tidak tuntas terdapat 26 siswa atau 69,42\%. Sedangkan data posttest diketahui terdapat 32 siswa atau $84,21 \%$ yang tuntas sedangkan 6 siswa atau $15,79 \%$ tidak tuntas.

Setelah diperoleh data, maka dapat dilanjutkan pengujian hipotesisnya, akan tetapi sebelum dilakukan pengujian hipotesis perlu dilakukan uji prasyarat analisis. Berdasarkan dua uji asumsi dasar yang dilakukan, dapat dilihat bahwa uji normalitas dengan Kolmogrof-Smirnov menunjukkan semua data dalam penelitian ini terdistribusi normal. Hasil uji homogenitas varians dengan Levene Statistic menunjukkan semua data berasal dari varian yang sama (homogen). Dengan terpenuhinya semua asumsi dasar tersebut, maka selanjutnya dapat dilakukan uji hipotesis melalui uji-t dengan Paired Sample T-Test. Hasil uji t diperoleh $t_{\text {hitung }}=7,607$ dan $t_{\text {tabel }}=2,026$. Karena $t_{\text {hitung }}>t_{\text {tabel }}$, maka $\mathrm{H}_{\mathrm{a}}$ diterima. Dengan ditolaknya $\mathrm{H}_{0}$ dari hasil pengujian uji t maka dapat disimpulkan bahwa model pembelajaran inkuiri terbimbing dapat meningkatkan kemampuan kognitif siswa.

Rendahnya rata-rata nilai pretest siswa ini disebabkan peserta didik kurang memahami materi yang telah diajarkan 
dengan menggunakan metode ceramah. Selain itu, guru menjadi satu-satunya sumber informasi sehingga mengakibatkan pelajaran tidak menarik bagi siswa dan perhatian siswa terhadap pelajaran berkurang. Hal ini sesuai dengan pendapat Slameto (2015: 57), yang menyatakan bahwa kegiatan belajar mengajar yang terpusat pada guru akan mengakibatkan keaktifan siswa tidak optimal, sehingga siswa menjadi bosan, pasif dan mencatat saja.

Tingginya nilai rata-rata posttest siswa dikarenakan peserta didik aktif berdiskusi dan melaksanakan percobaan sesuai dengan tahapan model pembelajaran inkuiri terbimbing sehingga kemampuan kognitif peserta didik meningkat. Menurut Hamalik (2010: 188), model pembelajaran inkuiri terbimbing melibatkan siswa dalam menjawab pertanyaan-pertanyaan guru. Siswa melakukan penyelidikan, sedangkan guru membimbing mereka kearah yang tepat/benar. Model inkuiri terbimbing masih memegang peranan guru dalam memilih topik/bahasan, pertanyaan dan penyediaan materi. Akan tetapi siswa diharuskan untuk mendesain atau merancang penyelidikan, menganalisis hasil dan sampai kepada kesimpulan.

Model pembelajaran inkuiri terbimbing dapat memberikan stimulasi atau pengantar peserta didik untuk dapat meningkatkan kemampuanya dalam menemukan konsep dan prinsip ilmiah secara mandiri sehingga kemampuan intelegensi peserta didik meningkat dan memberikan kemampuan daya ingat peserta didik dalam pembelajaran biologi, sehingga pembelajaran inkuiri terbimbing memberikan proses pengajaran menjadi Studen centered (Slameto, 2015: 57).

Keterlaksanaan model pembelajaran inkuiri terbimbing dapat dilihat juga dari hasil observasi. Nilai observasi adalah nilai keterlaksanaan model pembelajaran apakah terlaksana dengan baik atau tidak dan sebagai data pendukung penelitian. Berdasarkan hasil observasi, pelaksanaan model pembelajaran inkuiri terbimbing berlangsung baik. Hal ini dapat dilihat dari persentase indikator pada setiap pertemuan. Pencapaian indikator pada pertemuan pertama yaitu sebesar $81,25 \%$ termasuk kategori baik dan pada pertemuan kedua persentase pencapaian yaitu sebesar $87,50 \%$ termasuk kategori sangat baik. Maka dapat disimpulkan bahwa persentase pencapaian indikator berlangsung stabil dan meningkat dengan rata-rata pencapaian

Pencapaian indikator berlangsung stabil dan meningkat dengan rata-rata pencapaian indikator dengan persentase $84,37 \%$ termasuk kategori baik. Walaupun demikian ada beberapa hal yang menjadi evaluasi dari pelaksanaan model pembelajaran inkuiri terbimbing tersebut, yaitu: alokasi waktu/jam pelajaran yang sangat singkat menyebabkan kurang optimal dalam melakukan penelitian, belum terbiasanya siswa dengan pembelajaran inkuiri dan walaupun model pembelajaran yang digunakan sebagian besar adalah eksperimen namun tetap saja peran guru sebagai pemberi informasi masih dominan.

Secara umum, pada pertemuan pertama teramati bahwa siswa masih bingung bagaimana untuk merancang prosedur percobaan dan mengungkap pertanyaan dan pendapat saat persentasi. Kebingungan siswa dalam merancang prosedur percobaan disebabkan karena siswa belum terbiasa dengan menggunakan model pembelajaran inkuiri terbimbing. Dari hasil pengamatan, dari 6 kelompok hanya ada 2 kelompok yang dapat menyelesaikan tugas dengan baik. Menurut Wahyudin (2010: 59) dalam 
Anggraini, Fitriani dan Harmoko (2017: 14), mengatakan bahwa pada model pembelajaran inkuiri terbimbing ini guru tidak lagi berperan sebagai pemberi informasi dan siswa sebagai penerima informasi, tetapi guru membuat rencana pembelajaran. Siswa melakukan percobaan atau penyelidikan untuk menemukan konsep-konsep yang ditetapka oleh guru. Jadi, dari pendapat tersebut dapat disimpulkan bahwa masih sangat wajar jika pada pertemuan pertama ini masih ada siswa yang belum mampu menyelesaikan tugasnya karena mereka masih beradaptasi dan masih perlu bimbingan dari guru.

Selain itu, pada kegiatan pembelajaran pertemuan pertama berlangsung masih ditemukan beberapa siswa yang kurang aktif dalam pembelajaran. Hal ini dapat disebabkan karena model pembelajaran ini termasuk baru diterapkan di kelas ini. Kebanyakan siswa tetap pasif dan belum beradaptasi dengan perubahan model pembelajaran yang diajarkan guru. Hal ini sesuai dengan yang dikemukakan oleh Suryosubroto (2009: 186), bahwa model pembelajaran inkuiri terbimbing memiliki kelemahan antara lain dipersyaratkan keharusan kesiapan mental pada peserta didik untuk melaksanakan pembelajaran.

Pada pertemuan selanjutnya, siswa sudah mulai beradaptasi dan banyak siswa yang berani mengungkapkan pendapat dan mengajukan pertanyaan. Dari hasil pengamatan, dari 6 kelompok terdapat 4 kelompok yang dapat menyelesaikan tugas dengan baik sedangkan 2 kelompok lainnya masih terdapat perbaikan dan diberikan bimbingan dalam penyelesaian tugasnya. Namun hasil ini sudah mengalami peningkatan bila dibandingkan dengan pertemuan sebelumnya. Pada pertemuan ini siswa yang kurang aktif pada pertemuan sebelumnya menunjukkan kemajuan dengan ikut berpatisispasi dalam mempresentasikan hasil percobaan. Faktor penyebabnya yaitu siswa sudah memahami materi dan aktif dalam pembelajaran model pembelajaran inkuiri terbimbing. Menurut Lutfi (2013: 63) dalam Anggraini, Fitriani dan Harmoko (2017: 14), mengatakan bahwa model pembelajaran inkuiri terbimbing merupakan model pembelajaran yang membantu siswa memperoleh pengetahuan dengan cara menemukan sendiri.

\section{KESIMPULAN DAN SARAN}

Berdasarkan hasil penelitian didapatkan nilai rata-rata pretest 69,34 dan posttest 83,82 dengan hasil uji $t_{t} t_{\text {hitung }}=7,607$ dan $\mathrm{t}_{\text {tabel }}=2,026$ yang menunjukkan bahwa hipotesis $\mathrm{H}_{0}$ ditolak dan $\mathrm{H}_{\mathrm{a}}$ diterima. Dengan demikian dapat disimpulkan bahwa ada perbedaan kemampuan kognitif siswa sebelum dan setelah penerapan model pembelajaran inkuiri terbimbing. Saran penelitian selanjutnya dapat melengkapi aspek afektif dan psikomotorik.

\section{RUJUKAN}

Anderson, L., W., dan Krathwohl, D., R. 2001. A Taxonomy for Learning Teaching and Assesing: A Revision of Bloom's Taxonomy of Education Objectives. New York: Addison Wesley Longman, Inc.

Anggraini, R., N., Fitriani, L., dan Harmoko. 2017. Pengaruh Model Pembelajaran Inkuiri Terbimbing Terhadap Hasil Belajar Biologi Siswa Kelas XI IPA. Palembang: Universitas STKIP-PGRI Lubuk Linggau. Volume 1 Nomor 2.

Hamalik, O. 2010. Perencanaan Pendekatan Berdasarkan Pendekatan Sistem. Jakarta: Bumi Aksara. 
Sanjaya, W. 2006. Strategi Pembelajaran Berorientasi Standar Proses Pendidikan. Jakarta: Kencana.

Slameto. 2015. Belajar dan FAktor-Faktor yang Mempengaruhinya. Jakarta: Rineka Cipta

Sudarisman. S. 2015. Memahami Hakikat Dan Karakteristik Pembelajaran Biologi Dalam Upaya Menjawab Tantangan Abad 21 Serta Optimalisasi Implementasi Kurikulum 2013. 2 (1), 250

Suhardi. 2007. Pengembangan Sumber Belajar Biologi. Yogyakarta: FMIPA UNY.
Suryosubroto. 2009. Proses Belajar Mengajar di Sekolah. Jakarta: Rineka Cipta

Susanti. 2014. Metode Inkuiri Terbimbing Terhadap Hasil Belajar Sains Biologi Siswa Kelas VII SMP N 1 Ngawen. Yogyakarta: UIN Sunan Kalijaga.

Trianto. 2011. Mendesain Model Pembelajaran Inovatif Progresif. Jakarta: Kencana. 